DOI: https://doi.org/10.24867/14CG01Kojovic

\title{
RAZVOJ I PRIMENA MEHANIZACIJE ZA ZEMLJANE RADOVE KOD IZRADE TEMELJA I PODZEMNIH ETAZA OBJEKATA VISOKOGRADNJE
}

\section{DEVELOPMENT AND APPLICATION OF MECHANIZATION FOR GROUND WORKS IN CONSTRUCTION OF FOUNDATIONS AND BUILDINGS}

\section{Spasoje Kojović, Fakultet tehničkih nauka, Novi Sad}

\section{Oblast - GRAĐEVINARSTVO}

Kratak sadržaj - U radu je razmatran put izbora građevinske mehanizacije za izvođenje zemljanih radova, kao $i$ način rešavanja zaštite iskopa kod objekata visokogradnje nakon završenih zemljanih radova.

Ključne reči: zemljani radovi, građevinska mehanizacija, dijafragma, šipovi, iskop, obezbeđenje temeljnih jama

Abstract - The subject of this paper is selection of construction mechanization for groundworks, as well as the method of solving the way of protection of excavations at buildings after the completition of groundworks.

Keywords: groundworks, construction machines, diaphragm, piles, excavation, securing foundation pits

\section{UVOD}

Izgradnja građevinskih objekata danas podrazumeva primenu građevinske mehanizacije u svim sferama, za izvršenje različitih vrsta radova. Radovi u građevinarstvu se razlikuju i po obimu angažovane mehanizacije, pa oni radovi koji su u procesu izgradnje dominantni po obimu, impliciraju visok stepen mehanizovanosti i otvaraju problem izbora optimalne mehanizacije.

Sa aspekta predmeta ovog rada, akcenat će biti stavljen na visokogradnju i upotrebu, odnosno primenu mehanizacije kod izvođenja zemljanih radova vezanih za izradu temelja i podzemnih etaža. Većina radova kod ove vrste izgradnje vezana je za iskope, otkope i nasipe, ali ne isključuje se i prisustvo drugih zemljanih radova, u zavisnosti od uslova i vrste zemljanog materijala koji je predmet potrebe za delovanjem mehanizacije. Aktuelnost teme, naročito se može vezati za ekspanziju izgradnje objekata u urbanim sredinama, gde se nameću novi uslovi gradnje, brzi razvoj gradskih sredina, gde sama izgradnja višespratnica postaje sve komplikovanija.

\section{SPECIFIČNOSTI ZEMLJANIH RADOVA I OBLAST VISOKOGRADNJE}

Zemljani radovi predstavljaju grupu građevinskih radova na čijoj osnovi počivaju svi ostali radovi koji spadaju u jedan zaokruženi građevinski proces, drugim rečima izvode se bez obzira na predmet i vrstu izgradnje.

Kao prva grupa radova prilikom gradnje nekog objekta, javljaju se zemljani radovi.

\section{NAPOMENA:}

Ovaj rad proistekao je iz master rada čiji mentor je bio prof. dr Milan Trivunić.
Tehnološka rešenja sprovođenja zemljanih radova kod svakog konkretnog objekta, predstavljaju nezaobilazne segmente koji se sprovode u okviru:

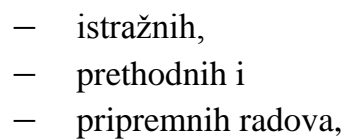

koji su neophodni da se sprovedu zbog svih radova koji posle slede. Kod tehnologije izvođenja građevinskih radova, naročito složenijih objekata poput objekata visokogradnje, veoma je važno obratiti pažnju na tlo gde se obavlja izgradnja objekta. Samo tlo gde se planira izgradnja građevinskog objekta, nije svuda i na svim lokacijama jednaka.

$\mathrm{Na}$ osnovu posebnih istraživanja, izvršena je kategorizacija tla u određene klase, odnosno grupe. Postoje $\mathrm{u}$ relevantnoj literaturi različita navođenja podela i vrsta tla. Pa tako, tlo se u odnosu na zemljane materijale, može podeliti na:

- $\quad$ stene (monolitna, trošna, raspucala);

- nevezani ili nekoherentni materijali (šljunak 460mm, pesak 0,4-6mm i dr.); i

- vezani ili koherentni materijali (prašina 0,002$0,06 \mathrm{~mm}$, glina manje od $0,0002 \mathrm{~mm}$ i dr.)

\section{PRIMENA MEHANIZACIJE ZA ISKOPE KOD OBJEKATA VISOKOGRADNJE}

Prvi zemljani radovi prilikom iskopa temelja javljaju se radovi vezani za uklanjanje površinskog sloja tla, odnosno obavlja se uklanjanje humusa.

- Uklanjanje humusa, u savremenom građevinskom procesu, obavlja se odgovarajućom građevinskom mehanizacijom. Kao najčešće korišćena građevinska mehanizacija za uklanjanje humusa, koriste se dozeri.

- Nakon uklanjanja humusa, pristupa se iskopu, odnosno pripremi terena za buduće temelje objekta koji se gradi. U tehnologiji zemljanih radova, najčešće se spominju dve osnovne vrste iskopa: široki iskop (namenjen uglavnom za podrumske objekte, podzemne etaže), i uski iskopi koji se koriste za izgradnju temelja za zidove objekta. Iskopi se takođe mogu podeliti na :

$\checkmark$ linijske iskope - podrazumevaju sve vrste kanala, rovova, trakastih temelja, tunela $\mathrm{i}$ drugo;

$\checkmark$ površinske iskope $-\mathrm{u}$ ovu grupu spadaju svi iskopi koji su površinski veći od njene dubine; 
$\checkmark \quad$ tačkasti iskopi - razne vrste šahtova i temelja samaca

U suštini, za većinu iskopa, utovara i transporta koriste se sledeće vrste građevinske mehanizacije: bageri, dozeri, grejderi, skreperi, utovarivači i različita transportna sredstva.

- Pored pripreme terena gde će se kopati iskopna jama, odnosno iskop za budući objekat, bitni radovi vezuju se i za tkzv. ugradnju materijala. U ovom slučaju misli se na radove vezane za transport, planiranje, razastiranje i zbijanje. I u ovom slučaju, veliku ulogu i procenat učešća $\mathrm{u}$ ovim radovima, zauzima građevinska mehanizacija. Dominantne poslove vezane za ovu vrstu radova obavljaju buldožeri i grejderi, mada su u primeni i utovarivači i skreperi, uz napomenu da se grejderi $u$ visokogradnji više koriste kod skidanja humusa i za radove planiranja i razastiranja, a manje za potrebe iskopa temeljnih jama ili se koristi za iskope jama dubine do $4 \mathrm{~m}$. - Zbijanje predstavlja završni deo ugradnje iskopanog materijala, i ujedno sa ovim postupkom se dolazi do poboljšanja karakteristika određenog tla. Primarni cilj ovih radova usmeren je ka postizanju boljih tehničkih svojstava tla povećanjem gustine materijala.

\section{ZAŠTITA I OBEZBEĐENJE ISKOPA}

Pored svih pripremnih radova oko istraživanja tla na kome će se graditi budući objekat visokogradnje, odnosno gde će se kopati temeljne jame, veoma je bitno kod zemljanih radova koji se izvode, izvršiti zaštitu iskopa po pitanju uticaja vode i obezbediti iskop od mogućeg urušavanja, sleganja, kako bi konstrukcija bila prvenstveno bezbedna i sigurna za druge radove koji slede.

Kod ovih radnji, naročito je važno u početku ispitati tlo od mogućnosti prodiranja podzemnih voda.

\subsection{Zaštita iskopa od vode}

Gradilište gde se planira izgradnja određenog objekta visokogradnje, mora da bude obezbeđeno svim potrebnim uslovima za radove koji će biti izvođeni. Jedan od važnih parametara, jeste da tlo gde se kopa temeljna jama, mora biti suvo. Drugim rečima, vlažnost tla mora biti u granicama dozvoljenog, koje stoji i predmet je proračuna u svakom projektu vezanom za gradnju. Iz tog razloga potrebno je osigurati dobru odvodnju i sistem zaštite od raznih oblika prodora vode.

Zaštita iskopa od vode usmerena je u tri pravca, i to:

- zaštita od spoljašnje atmosferske vode,

- zaštita od atmosferske vode koja direktno upada u iskop (direktna ili atmosferska voda) i

- zaštita od podzemnih voda (snižavanjem njenog nivoa)

Problem prisustva vode nije toliko veliki kada je kota vode ispod kote iskopa i u tom slučaju ne moraju da se izvode dodatni radovi. Problem nastaje kada je nivo podzemnih voda (NPV) iznad kote iskopa. Tada se moraju izvoditi dodatni građevinski radovi kojima se snižava nivo podzmenih voda i na taj način obezbeđuje suvo tlo za radove u iskopnoj, odnosno temeljnoj jami.
Snižavanje NPV obavlja se uz pomoć drenažnih sistema u koje spadaju:

- radovi na direktnom crpljenju vode,

- horizontalna drenaža na obodu iskopa(muljne pumpe),

- vertikalna drenaža pomoću iglo filtera, dubokih bunara i slično.

\subsection{Dijafragme}

Prilikom gradnje konstrukcija sa podzemnim etažama ili dubokim temeljima, potrebno je izvršiti iskop tla veće dubine. Ukoliko nije moguće izvršiti široki iskop (iskop sa stranicama $\mathrm{u}$ nagibu pod uglom koji obezbeđuje stabilnost kosine), u slučaju blizine susednog objekta, npr., iskop se vrši vertikalno, uz izradu privremene ili stalne potporne (zaštitne) konstrukcije koja osigurava stabilnost stranice iskopa, odnosno sprečava obrušavanje tla u jamu.

Armirano betonska dijafragma predstavlja konstrukciju u obliku zida koji se izvodi u tlu, duž granice budućeg iskopa temeljne jame. Iskop za dijafragmu se radi pomoću specijalnog bagera (obično bager grajfer), jama se ispunjava isplakom (suspenzija bentonitne gline $\mathrm{u}$ vodi) koja sprečava urušavanje iskopa. Nakon iskopa se u rov spušta atmaturni koš, a zatim vrši betoniranje pomoću kontraktorske cevi, od dna na gore. Debljina zida dijafragme je najčešće 60 ili $80 \mathrm{~cm}$.

Dijafragme su armirano betonski zidovi koji se po specijalnom postupku grade neposredno u terenu.Koriste se kao zaštita bočnih strana temeljne jame i/ili kao sastavni deo budućeg objekta. Mogu se koristiti i kao vodozaštitini elementi.

\section{3. Šipovi - zavesa šipova}

Šipovi su vrsta temelja koja opterećenje od objekta prenose kroz površinske slojeve tla slabe nosivosti do dubljih slojeva tla dobre nosivosti. Time se otklanja mogućnost većeg sleganja objekta što doprinosi njegovoj statičkoj sigurnosti. Ako se šipovi izvode na samom terenu onda se to može izvesti postupkom utiskivanja $\mathrm{u}$ tlo bušenjem ili pobijanjem. U naseljenim područjima koriste se bušeni šipovi jer je buka pri ugrađivanju umerena.

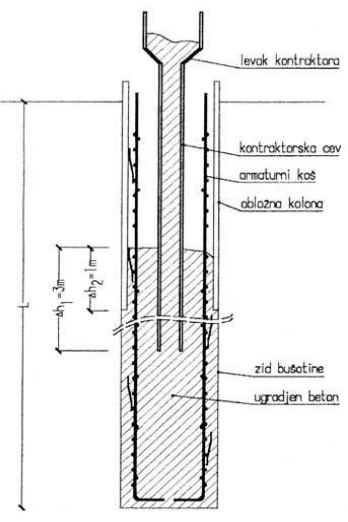

Slika 1. - Betoniranje šipova 
Betoniranje šipova obavlja se kontraktorskim postupkom. Vreme početka vezivanja betona ne sme biti kraće od 2 sata.

Betoniranje šipova obavlja se kontraktorskim postupkom (Slika 1). Početak betoniranja obavlja se spuštanjem kontraktorske cevi na visinu $20 \mathrm{~cm}$. od dna bušotine. Betoniranje šipa treba izvršiti bez prekida.

\section{IZBOR NAČINA FUNDIRANJA}

Izbor metode temeljenja, odnosno fundiranja, zavisi od mnogo bitnih činilaca, a do kojih se dolazi raznim istražnim radovima. Prvenstveno, nakon što se istraži tlo gde se predviđa izgradnja buduće građevine, donosi se odluka o načinu temeljenja, koje može biti plitko i duboko. Pored navedenih oblika izrade temelja, oni se mogu razlikovati i na osnovu sledećih parametara: po obliku poprečnog preseka, po materijalu od kojega su napravljeni, po načinu prenošenja opterećenja, po konstruktivnom sklopu i slično

\subsection{Plitko fundirani temelji}

Plitka fundiranja podrazumevaju takvu izradu temelja gde se u površini stope, prenose kose, centralne i ekscentričnesile. Osnovni uslov koji treba da se postigne jeste da dnostope bude ispod minimum od $80 \mathrm{~cm}$, što predstavlja krajnju tačku smrzavanja. U retkim slučajevima može doći do odstupanja od ovog pravila, i to u slučajevima kada zgrade imaju privremeni karakter (pomoćne zgrade) ili kod temeljenja na stenskoj podlozi.

\subsection{Duboko fundirani temelji}

Kod zemljišta koje nije u stanju da neposredno prihvati opterećenja od zgrade (kako sopstvenu težinu tako i korisna opterećenja ali i seizmičke i druge uticaje) pribegava se specifičnim rešenjima. To su duboka fundiranja ili drugačije nazvana fundiranja na šipovima. Suštinski, ovi veoma zahtevni konstruktivni i izvođački načini temeljenja zasnovani su na principu prenošenja opterećenja na stabilno tlo koje se pronalazi na velikoj dubini u odnosu na uobičajene dubine fundiranja.

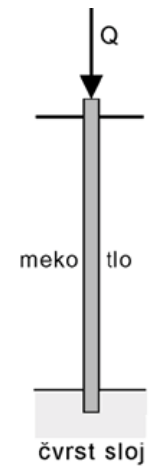

( a )

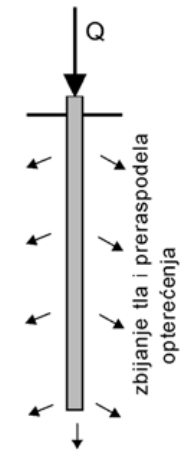

( b )

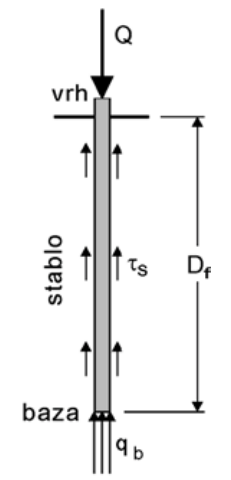

(c)
Slika 2. Primena šipa i prenošenje vertikalnog opterećenja

Dubokim temeljima se opterećenje prenosi na izvesnu dubinu ispod korisnog dela građevinske konstrukcije. Osnovna ideja primene šipova prikazana je na Slici 2, kada se u površinskoj zoni nalazi sloj meke gline a na većoj dubini postoji mogućnost prenošenja opterećenja na tlo veće nosivosti (Slika 2.-a), ili se pobijanjem šipa postiže prenošenje opterećenja na veću masu tla uz eventualno povećanje njegove zbijenosti (Slika 2.-b). U opštem slučaju, vertikalno opterećenje $Q$ koje deluje na vrh, (gornji kraj), šipa (Slika 2.-c) prenosi se preko smičućih napona $\boldsymbol{\tau}_{\boldsymbol{s}}$ na kontaktu između stabla šipa $\mathrm{i}$ tla $\mathrm{i}$ vertikalnih komponenti normalnih napona $\boldsymbol{q}_{\boldsymbol{b}}$ koji deluju na bazu šipa.

Pomoću šipova vrši se posredovanje između zgrade i stabilnog tla. Prema vrsti šipova razlikujemo tri slučaja:

$\checkmark$ Fundiranje na stojećim šipovima- princip prenošenja opterećenja na nosive slojeve tla koji leže dublje.

$\checkmark$ Fundiranje na plivajućim (lebdećim) šipovima opterećenje se ne prenosi neposredno na nosivo tlo, već na slojeve koji mogu da se sabiju.

$\checkmark$ Fundiranje na tonućim bunarima

\section{NAČIN I PRIKAZ IZBORA ODGOVARAJUĆE MEHANIZACIJE NA OSNOVU KRITERIJUMA}

Kako se izvođenje zemljanih radova danas ne može zamisliti bez upotrebe građevinske mehanizacije, mašine koje su planirane za ovu grupu radova treba da budu optimalno izabrane i usklađene za konkretan zadatak koji obavljaju. Zato je bitno detaljno proučiti:

- mogućnosti primene pojedinih mašina za izvršenje radova na određenom gradilištu (izabrana tehnologija građenja, prostor, komunikacije, uslovi rada na gradilištu,...),

- karakteristike pojedinih mašina (gabarit, teorijski učinak, brzina rada, zahtevi za podlogom i sl.), koje su date tehničkom specifikacijom ili prospektom proizvođača.

Postupak izboragrađevinske mehanizacije za zemljane radove biće prikazan u tri faze odlučivanja:

- I faza odlučivanja: širi izbor mehanizacije,

- II faza odlučivanja: uži izbor mehanizacije i

- III faza odlučivanja: izbor mehanizacije metodom višekriterijumske optimizacije.

\subsection{I faza odlučivanja - širi izbor mehanizacije}

Pri širem izboru mehanizacije potrebno je definisati zadatke građevinske mehanizacije, raščlaniti tehnološki proces na pojedine radne operacije, sagledati raspoložive mašine, proučiti uslove koje mašina treba da ispuni, izvršiti izbor mašina koje odgovaraju usvojenoj tehnologiji i odabrati mašinu koja može izvršiti zadatu operaciju.

\subsection{II faza odlučivanja - uži izbor mehanizacije}

Uži izbor mehanizacije ima zadatak da od mogućih mašina ukaže na one koje pružaju najveću ekonomsku prednost, tj. najveće mogućnosti uz najniže troškove. Da bi se izvršio uži izbor mehanizacije potrebno je za svakumašinu izračunati praktični učinak i cenu časa rada pojedinih mašina.

Praktični učinak je stvarni učinak građevinske mašine na određenom gradilištu i pod određenim uslovima eksploatacije.Teorijski učinak je učinak građevinske mašine koji se može ostvariti pod optimalnim uslovima eksploatacije.

Opšta formula za sračunavanje praktičnog učinka je:

$$
\mathrm{U}_{\mathrm{p}}=\mathrm{U}_{\mathrm{t}} \mathrm{k}_{\mathrm{p}} \mathrm{k}_{\mathrm{v}} \mathrm{k}_{\mathrm{r}} \ldots \ldots \mathrm{k}_{\mathrm{n}}(1)
$$


gde su:

- $\mathrm{U}_{\mathrm{p}}$ - praktični učinak,

- $\mathrm{U}_{\mathrm{t}}$ - teorijski učinak,

- $\quad \mathrm{k}\left(\mathrm{k}_{\mathrm{p}}, \mathrm{k}_{\mathrm{v}} \mathrm{k}_{\mathrm{r}} \ldots \ldots . . \mathrm{k}_{\mathrm{n}}\right)$ - koeficijenti korekcije.

Cena časa rada građevinske mehanizacije je jedan od presudnih elemenata za izbor mašina za izvršenje pojedinih radova.

Cena časa rada građevinske mašine obuhvata:

- troškove osnovnog sredstva,

- eksploatacione troškove,

- troškove režije i dobiti.

\subsection{III faza odlučivanja-višekriterisjka optimizacija}

Višekriterijumska optimizacija je postupak koji na osnovu usvojenih kriterijuma određuje najbolje rešenje određenog problema. U svakom slučaju potrebno je izvršiti izbor mašina koje obavljaju određene operacije za izvođenje zemljanih radova. Veliki broj različitih mašina koje se mogu iskoristiti za ove radove, kao i zahtevi koje te mašine moraju ispuniti, otvaraju problem izbora najpovoljnijeg tipa mašine. Ukoliko se problem izbora posmatra za veći broj mogućih rešenja, a analiza obuhvata različite aspekte vrednovanja, on spada u problem višekriterijumske optimizacije. Rešavanje ovog problema podrazumeva uključivanje adekvatne metode višekriterijumske optimizacije.

\section{ZAKLJUČAK}

Izgradnja nekog objekta započinje odabirom lokacije na kojoj će se zidati budući objekat. Veoma bitne aktivnosti vezane za sam objekat, jesu istražni i prethodni radovi, gde je akcenat na ispitivanju tla na kome će se izgraditi neki objekat. Navedene aktivnosti predstavljaju predmet istraživanja koji prethodi pristupanju zemljanim radovima. Ovi radovi u sebi sadrže potrebne aktivnosti koje su neophodne da bi kvalitet izvođenja ove grupe radova bio na visokom nivou. Kao najznačajnija vrsta radova u vezi zemljanih radova, jesu iskopi, odnosno priprema tla gde će se graditi temelj nekog objekta, koji pripada u ovom slučaju oblasti visokogradnje.

Veoma bitna karakteristika u vezi sa iskopom jeste karakteristika tla koje se iskopava, ali i na osnovu kojeg se vrše sve ostale potrebne radnje, kako bi iskopna jama bila adekvatno pripremljena za dalje radove, odnosno da bi bila bezbedna i sigurna. Veliku ulogu u zemljanim radovima uopšteno ima građevinska mehanizacija, bez koje je danas nezamislivo pristupiti izgradnji bilo kog objekta, naročito u oblasti visokogradnje. Širok spektar mehanizacije omogućava da se na efikasan i projektovan način obave svi pripremni radovi, radovi na ugradnji materijala, radovi u vezi sa iskopom, kao i obezbeđenja iskopnih jama.
Obezbedenje iskopa diktiraju parametri koji se tiču isključivo uslova u kojima se radovi izvode. Blizina susjednih objekata je bitan faktor koji utice na način obezbeđenja temeljnih jama,zbog kojih se pribegava privremenoj ili trajnoj zastitnoj konstrukciji koja obezbeđuje sigurnost stranica iskop. Pored toga bitno za napomenuti jeste dubina podzemnih etaža dovodi do izbora tipa obezbeđenja iskopa. Potporne konstrukcije ukoliko se radi o $\mathrm{AB}$ elementima (dijafragme ili šipovi) mogu da predstavljaju vertikalne oslonce prilikom izgradnje medjuspratnih konstrukcija.

Kroz analizu relevantnih aspekata vezanih za poslove u vezi iskopa temelja, koji podrazumevaju niz vezanih vrsta radova (otklanjanje humusa, iskop, razastiranje, planiranje, zbijanje), kao i veoma značajnih faktora koji utiču na stabilnost iskopne jame, poput nivoa podzemnih voda i obezbeđenja temeljne jame od odrona i urušavanja iskopanog materijala, može se zaključiti da je bez primene mnogobrojne građevinske mehanizacije, kao i tehnoloških rešenja koje se nude prilikom ove grupe poslova na gradilištu, nemoguće bilo sagraditi stabilan i siguran objekat, koji teži određenoj višegodišnjoj nameni.

Izvođenje građevinskih radova zahteva brzo donošenje odluka i smanjenje rizika donošenja ispravnih odluka. U tom cilju primenjujemo korišćene metode analize i sinteze pri odabiru mogućih varijantnih rešenja i metoda višekriterijumske optimizacije pri izboru optimalnih mašina za izvršenje zemljanih radova. Primenom ovih metoda dobijaju se brzo kvalitetne informacije koje povoljno utiču na tok i kvalitet izgradnje objekta.

\section{LITERATURA}

[1] Ćirović G., Mitrović S.: „Tehnologija građenja“, Visoka građevinsko-geodetska škola, Beograd, 2007.

[2] Trivunić, M., Matijević, Z.: „Tehnologija i organizacija građenja“, praktikum,Univerzitet u Novom Sadu, FTN, 2009.

[3] Opricović, S.: „Optimizacija sistema“, Građevinski fakultet, Beograd, 1992.

\section{Kratka biografija:}

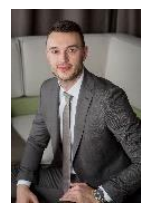

Spasoje Kojović rođen je u Trebinju 1989. god. Master rad na Fakultetu tehničkih nauka iz oblasti Gradjevinarstva-Tehnologija i organizacija građenja odbranio je 2021 .

kontakt: skojovic@live.com 